\title{
PREDICTING THE INNOVATIVE WORK BEHAVIOR BY ASSESSING LEADERSHIP STYLES IN A HIGHER EDUCATIONAL CONTEXT Muhammad Saqib Khan ${ }^{*}$, Hamid Khan ${ }^{2}$, Aman Ullah ${ }^{3}$, Muhammad kamran ${ }^{4}$, Muhammad Tariq ${ }^{5}$ \\ ${ }^{1 *}$ Institute of Business Administration, Gomal University, Dera Ismail Khan, Pakistan; ${ }^{2,4}$ Lecturer, Institute of Business Administration, Gomal University, Dera Ismail Khan, Pakistan; ${ }^{3}$ Assistant Professor, Institute of Business Administration, Gomal University, Dera Ismail Khan, Pakistan; ${ }^{5}$ Associate Professor, Department of Management Sciences, University of Haripur, Pakistan.
}

Email: ${ }^{1 *}$ saqiblecturer@gmail.com, ${ }^{2}$ hamid_nido@gmail.com, ${ }^{3}$ amanu_khattak@ hotmail.com, ${ }^{4}$ kamrangul9006@gmail.com

Article History: Received on $27^{\text {th }}$ June 2021, Revised on $12^{\text {th }}$ July 2021, Published on $17^{\text {th }}$ July 2021

\begin{abstract}
Purpose of Study: The present study aimed to examine the leadership styles (transformational \& transactional) in predicting the innovative work behavior of the teacher in higher educational institutions. Leadership is important in the transformation of attitude and behavior of followers towards assigned responsibilities, however, which style is more effective in this transformation process in the main theme of the present study.
\end{abstract}

Methodology: To achieve the desired objectives of the research, a quantitative approach was used wherein the crosssectional design was followed by using the survey approach to attain the objectives as aligned with hypotheses. In this connection, relationships (association \& cause-\&-effect) among research variables were examined through statistical procedures by using SPSS.

Main Findings: The results of the study revealed that both the leadership styles are effective in the transformation process however, the role of transformational leadership is more effective as compared to transactional leadership as revealed from the results of correlation (association) and regression (cause-\& effect) procedures in the context under considerations in this research study.

Applications of Study: The study is likely to be useful for the management of higher education institutions in revisiting their policies concerning the application of leadership development towards the followers. The study is also expected to be useful for future researchers in obtaining the practical guidelines from methods and procedures used in this study for their future endeavors.

Novelty/Originality of Study: This study examined the leading and burning issues like (leadership styles and followers' innovative behavior in a native environment to produce new findings and new knowledge about the relationships between the research phenomena to contribute to the existing database of knowledge.

Keywords: Transformational Leadership, Transactional Leadership, Innovative Work Behavior, Higher Education.

\section{INTRODUCTION}

In the contemporary era, the social and economic transformation, environmental sustainability, and continuous disparities in health and cultural values, education have been considered as the main actor and leading sources to cater to the situation overwhelmed at the sustainable development (Sánchez \& Mainardes, 2016). In this connection, the role of higher education is indispensable in promoting the sense of responsibility and values overwhelmed at social, cultural, and economic errands that further lead to nurture the attitude and behavior of future professionals towards sustainable development (Gómez, Pujols, Alvarado \& Vargas, 2018). In defining and responding to the leading challenges mainly concerned with the academic, social, and cultural values, higher education has played a significant role in promoting an effective culture of teaching and learning wherein attitude and behavior are transformed for particular purposes (Vasilescu, Barna, Epure \& Baicu, 2010). In this process of transformation, the main responsibility falls upon the shoulders of leadership in higher education who is responsible for ensuring effective involvement of followers in the behavioral transformation toward certain objectives (Asad, Ismail, Hussain \& Alghazali, 2020). For this purpose, leadership is vital in determining the work behavior of the followers towards the assigned responsibilities.

Leadership is important in the contemporary era due to globalization, technological changes, and innovative work practices that lead the higher institutions in the adaptation of various strategies that aim at improving the working potential and conducive environment to safeguard the values and standards in the institutions (Asare, Long \& Murphy, 2005). The leadership through different traits and styles makes every effort to inspire the workforces towards the desired objectives wherein the transformational and transactional are widely recognized and researched with diverse outcomes (Eisenbeiss, Knippenberg \& Boerner, 2008). Academic leadership is important in motivation, and effectiveness towards the entire system of higher education (Siddique, Aslam, Khan \& Fatima, 2011). Transformational leadership is effective in determining the needs and motivation of the employees through the transformational process towards the desired objectives wherein the efforts, values, and potential are highly recognized (Kurt \& Yahyagil, 2015). Transactional leadership is vital in determining the desired values and efforts through an exchange process wherein reward and 
punishment are offered in exchange for efforts towards desired objectives (Kark, Dijk \& Vashdi, 2018). Consequently, both leadership styles are effective in determining employees' attitudes and behavior.

The innovative work behavior is the outcome of various efforts on the part of employees, leadership and institution as it is critical to recognize the factors that promotes followers' innovative work behavior (Škudienè, Augutytè, Demeško \& Suchockis, 2018). The leadership theories emphasized encourage creativity and innovation as leaders' primary function which is mainly ensured by transformational leaders while studies revealed that transactional leaders lack the ability to inspire employees towards innovative work behavior (Cheng, Cao, Zhong, He \& Qian, 2019). The work behavior is important for the determination of desired objectives that needs the inspiration from concerned leadership towards competitive advantages thus overwhelmed at creative thinking in the employees (Asad, Ismail, Hussain \& Alghazali, 2020). Innovation and creativity are mainly the outcomes of the leadership motivation on persistent manners through different traits which are critical in determining their behavior towards the assigned tasks leading to the development of the concerned institution (Alheeta, Ahmad, Ahmad \& Mohamed, 2021). In this connection, this study aimed to examine the leadership behavior (transformational \& transactional) in determining innovative work behavior of employees in the context of higher institutions in developing countries like Pakistan.

\section{RESEARCH OBJECTIVES}

1. To determine the leadership behavior (transformational \& transactional) in determining the teachers' innovative work behavior.

2. To examine the association between leadership behavior (transformational $\&$ transactional) and teachers' innovative work behavior.

3. To examine the cause- \&-effect relationship between leadership behavior (transformational \& transactional) and teachers' innovative work behavior.

\section{LITERATURE REVIEW}

Leadership in higher education has been recognized as a leading phenomenon toward desired sustainable development as it is vital to consider the developmental process from every possible dimension to ensure the expected objectives (Kezar, Rozana \& Melissa, 2006). The leadership is critical in determining the process of rehabilitation to ensure the aims and objectives are supported through norms and values about leadership behavior and followers' responses (Bolden, Georgy \& Jonathan, 2009). The distributive role of leadership has been recognized as the leading source for the development of attitude and behavior towards desired tasks that ensures the journey from survival to development (Sandra, Geraldine \& Kevin, 2014). The leadership through different styles is effective towards the determination of desired goals that can be possible only through the efforts, potential of the employees as the outcome of the leaders' encouragement towards desired objectives (Naqvi, Ullah \& Javed, 2017). The transformational leader is regarded as inspiring, motivational, humanistic, and influential whereas focus remained on future needs and long-term issues (Cheng, Cao, Zhong, He \& Qian, 2019) while the transactional leader is considered as goal-oriented whereas focus remained on objectives setting, evaluation and directing the outcomes (Alheeta, Ahmad, Ahmad \& Mohamed, 2021). Therefore, different leadership styles are effective in determining institutional tasks and success.

\section{Leadership Styles}

The leadership is phenomenal in determining the desired objectives and workforce responses over their efforts towards the attainment of leading strategic goals that are the outcome of inspiration from the leadership and commitment from the workforce (Shalley \& Gilson, 2004). The leaders' foremost effort is to empower the employees by using innovative techniques to make their own decision to contribute to the institutional development which needs the leaders' attention and employees' responsiveness (Zhang \& Bartol, 2010). In this connection, along with the leadership behavior, certain other factors are responsible for shaping or breaking the innovative behavior of the employees in the concerned institutions (Li \& Zheng, 2014). Among the various parameters, the leadership different styles are more effective in determining the innovative and creative behavior of employees that ensures employees' effective participation in institutional tasks leading to strategic objectives (Naqvi, Ullah \& Javed, 2017). In this connection, transactional and transformational leadership are widely recognized as leading traits towards employees' attitude and behavior in different contexts including higher education (Asad, Ismail, Hussain \& Alghazali, 2020). This study examined the role of transformational and transactional leadership in defining innovative work behavior.

\section{Transformational Leadership}

The leaders' influential role towards employees' motivation is insignificant which has been recognized in diverse contexts with diverse outcomes wherein some are participative while some are authoritative in determining the institution values and employees' innovative responsiveness (Gilson \& Shalley, 2004). Transformational leaders are effective in providing support to followers in attaining the desired tasks and responsibilities to maintain the competitive advantages in the most competitive environment (Erdogan \& Enders, 2007). Transformational leaders are recognized as the vital predictor for innovation and creativity leading to innovative behavior (Khan, Aslam \& Riaz, 2012). These leaders are effective in the assurance of creative behavior through a transformational process to inspire the workforces 
towards desired outcomes through undaunted efforts and commitment (Afsar, Badir \& Saeed, 2014). The transformation leader is efficient in producing the desired tasks and objectives to idealized influence and intellectual stimulation to ensure the effectiveness in the outcomes and efficiency in efforts (Wu \& Lin, 2018). These leaders are ideals for their followers in institutions due to critical attributes of inspirational motivation and individualized considerations $\underline{(\text { Alheeta, }}$ Ahmad \& Mohamed, 2021). The literature shows that transformational leader is active than transactional leaders.

\section{Transactional Leadership}

Transactional leaders are more popular regarding their exchange behavior wherein rewards and punishments are provided and based upon the levels of efforts, potential, and achievements (Janssen \& Yperen, 2004). Transactional leaders are goal-oriented that focused on results and never accept deviation from the desired standards (Sendjaya, Sarros \& Santora, 2008). The leaders are concentrated more on the achievements rather focus on the followers' needs that creates the confusion in minds and body interactions of the concerned workforce at workplaces (Voon, Lo, Ngui \& Ayob, 2011). These confusions further lead the employees towards the stress and apprehensions in connection to leaders' behavior and employees' responsiveness through the effective efforts towards determination of institutional tasks (Kwasi \& Emmanuel, 2015). Thus, the leaders are more determined about the institutional tasks and employees' efforts which leaders try to make the balance through exchanged behavior to ensure effective participation in the tasks and goals (Wu \& Lin, 2018). Thus, leaders are more critical of the institutional strategic standards and goals to determine the desired outcomes (Asad, Ismail, Hussain \& Alghazali, 2020). These leaders are effective towards employees' inspiration through management by exception active and passive.

\section{Innovative Work Behavior}

Innovation and creativity are the dire need of organizations in contemporary competitive and leading environments wherein the focus remained on the creative behavior to ensure the desired outcomes (Gilson \& Shalley, 2004). The innovation helps the employees to produce the novel and latest ideas that need the motivated behavior towards the implementation of these ideas to get the desired outcomes by utilizing the resources efficiently (Mukherjee \& Ray, 2009). The creative behavior is significant to ensure the desired consequences which is basically the outcomes of the individuals and institutional performance in diverse situations towards diverse desired standards (Barrick, Mount \& Li, 2013). In this connection, the role of leadership is significant in determining the employees' behavior towards innovation and creativity to set a side the traditional ways for the achievement of desired tasks (Carlo, Jean \& Boudrias, 2015). Transformational leaders are more effective in promoting creativity and innovation through the transformational process of behavior (Afsar \& Umrani, 2019). The transactional is also effective in managing the innovativeness through exchanges relationships thereby offering various rewards packages to inspire employees towards desired outcomes in institutions (Alheeta, Ahmad, Ahmad \& Mohamed, 2021). Thus, both leadership styles are effective in their own spheres towards the innovative work behavior in the institutions.

\section{RESEARCH HYPOTHESES}

The hypotheses have been developed from the main theme of the current study based upon possible relationships among research variables like predicting variables (transformational \& transactional) leadership styles and a criterion variable (innovative work behavior) which have been supported through the existing research studies.

$\mathbf{H}_{1}$ : There is a positive and significant association between the transformational leadership and innovative work behavior.

$\mathbf{H}_{2}$ : There is a positive and significant association between transactional leadership and innovative work behavior.

$\mathbf{H}_{3}$ : The transformational leadership has a positive and significant impact on the innovative work behavior.

$\mathbf{H}_{\mathbf{4}}$ : The transactional leadership has a positive and significant impact on the innovative work behavior.

\section{RESEARCH METHODOLOGY}

The methods and procedures used for conducting the present study have been presented in this section which thus helps in understanding the objectives and the manners through which these objectives have been achieving.

\section{Design and Approach}

The cross-sectional research design was used thereby ensuring the quantitative approach to offer the statistical relationships among the research variables. The survey approach was used to access the population of this study in order to get their views about the research phenomena under the considerations in this research. The positivism approach was used as philosophical consideration to conduct the study in a native environment in order to attain the desired objectives systematically.

\section{Population \& Sample}

The population of the study comprises the teachers from the selected higher educational institutions in the southern region of KP, Pakistan. There was total 1620 teachers in these institutions wherein the sample (320) was selected by 
using the statistical formula (Yamani, 1967). Consequently, total questionnaires were distributed among the teachers wherein 300 were recollected and used for data analysis to find answers to hypotheses.

\section{Data Collection \& Analysis}

The data collection is an essential element in the research process that ensures the collection and relevant facts and figures in order to guarantee the achievement of desired objectives. The secondary data was collected through the most relevant articles on relevant issues while primary data was collected through a structured questionnaire adapted from the existing research studies which were widely used in different research studies.

\section{Questionnaire Design \& Scale}

An adapted version of the questionnaire was used wherein the scale has been adopted from previous studies about research variables like leadership styles and innovative work behavior. Consequently, the scale regarding leadership styles have been adopted from the previous study (Avolio \& Bass, 2000) while the scales for the innovative work behaviors has been adopted from the previous study (Scott \& Bruce, 1994). These scales have already been by various researchers for conducting their research studies in the different contexts with different outcomes. Similarly, 5-point Likert scale was used to record the responses.

\section{RESULTS \& DISCUSSION}

The results as outcomes of the statistical procedures have been presented in this section with the aim to chase the hypotheses and to reach the conclusion. The results have been validated over the results of previous research studies to make clear the position of the present study in the existing database of research about the leadership role in determining the innovative work behavior in the context of higher educational institutions.

$\mathbf{H}_{\mathbf{1}}$ : There is a positive and significant association between transformational leadership and innovative work behavior.

Table 1: Correlation Analysis $\left(\mathrm{H}_{1}\right)$

\begin{tabular}{lll}
\hline & \multicolumn{2}{c}{ Transformational Leadership } \\
\hline Transformational Leadership & \multicolumn{2}{l}{ Pearson Correlation } \\
\cline { 2 - 3 } & Sig. (2-tailed) & \\
\cline { 2 - 3 } & $\mathrm{N}$ & \\
\hline Innovative Work Behavior & Pearson Correlation & $.725^{* *}$ \\
\cline { 2 - 3 } & Sig. (2-tailed) & .000 \\
\cline { 2 - 3 } & $\mathrm{N}$ & 300 \\
\hline **. Correlation is significant at the 0.01 level (2-tailed). \\
\hline
\end{tabular}

The results of correlation confirmed the association between the transformational leadership and innovative work behavior which was proposed through the first hypothesis. The results revealed the positive and significant association (.725 \& .000). Therefore, from the correlation results, the first hypothesis about the association is accepted. The results have been validated and confirmed via the results of previous research studies (Alheeta, Ahmad, Ahmad \& Mohamed, 2021; Škudienė, Augutyte, Demeško \& Suchockis, 2018; Kurt \& Yahyagil, 2015; Eisenbeiss, Knippenberg \& Boerner, 2008; Khan, Aslam \& Riaz, 2012; Afsar, Badir \& Saeed, 2014). Therefore, the existing research thus provides significant support.

$\mathbf{H}_{2}$ : There is a positive and significant association between transactional leadership and innovative work behavior.

Table 2: Correlation Analysis $\left(\mathrm{H}_{2}\right)$

\begin{tabular}{|c|c|c|}
\hline & & Transactional Leadership \\
\hline \multirow[t]{3}{*}{ Transactional Leadership } & Pearson Correlation & \\
\hline & Sig. (2-tailed) & \\
\hline & $\mathrm{N}$ & \\
\hline \multirow[t]{3}{*}{ Innovative Work Behavior } & Pearson Correlation & $-.457^{* *}$ \\
\hline & Sig. (2-tailed) & .000 \\
\hline & $\mathrm{N}$ & 300 \\
\hline
\end{tabular}

The correlation results confirmed the existence of an association between transactional leadership and work innovative behavior that was hypothesized over the second hypothesis. The results showed a significant but negative association ($.457 \& .000)$. Consequently, from the results of correlation, the second hypothesis regarding the association is rejected. Correlation results have been confirmed and validated through the previous studies results (Wu \& Lin, 2018; Carlo, Jean \& Boudrias, 2015; Kurt \& Yahyagil, 2015; Eisenbeiss, Knippenberg \& Boerner, 2008; Mukherjee \& Ray, 2009). Thus, the existing literature hence provides significant support.

$\mathbf{H}_{3}$ : Transformational leadership has a positive and significant impact on innovative work behavior. 
Table 3: Regression Analysis $\left(\mathrm{H}_{3}\right)$ (Model Summary)

\begin{tabular}{ccccc}
\hline Model & R & R Square & Adjusted R Square & Std. Error of Estimate \\
\hline 1 & $.725^{\text {a }}$ & .525 & .523 & .30760 \\
\hline
\end{tabular}

a. Predictors: (Constant), Transformational Leadership

Table 4: Regression Analysis $\left(\mathrm{H}_{3}\right)$ (ANOVA)

\begin{tabular}{lllllll}
\hline Model & Sum of Squares & df & Mean Square & F & Sig. \\
\hline \multirow{2}{*}{1} & Regression & 20.746 & 1 & 20.746 & 219.254 & $.000^{\mathrm{b}}$ \\
\cline { 2 - 7 } & Residual & 18.735 & 198 & .095 & & \\
\cline { 2 - 6 } & Total & 39.481 & 199 & & & \\
\hline \multicolumn{2}{l}{ a. Dependent Variable: Innovative Work Behavior } \\
\hline b. Predictors: (Constant), Transformational Leadership & & \\
\hline
\end{tabular}

Table 5: Regression Analysis $\left(\mathrm{H}_{3}\right)$ (Coefficients)

\begin{tabular}{|c|c|c|c|c|c|c|}
\hline \multirow{2}{*}{\multicolumn{2}{|c|}{ Model }} & \multicolumn{2}{|c|}{ Unstandardized Coefficients } & \multirow{2}{*}{$\frac{\text { Standardized Coefficients }}{\text { Beta }}$} & \multirow[t]{2}{*}{$\mathbf{t}$} & \multirow[t]{2}{*}{ Sig. } \\
\hline & & $\mathbf{B}$ & Std. Error & & & \\
\hline \multirow[t]{2}{*}{1} & (Constant) & 1.640 & .098 & & 16.716 & .000 \\
\hline & Transformational Leadership & .397 & .027 & .725 & 14.807 & .000 \\
\hline
\end{tabular}

The results from regression confirmed the positive and significant impact of transformational leadership on the teachers' innovative work behavior that was predicted through the third hypothesis by using the regression procedure. The results further revealed that transformational leadership has a significant impact on innovative work behavior through $52.5 \%$ change in R square as well as the significant impact (.397 \& .000). from these results of regression, the third hypothesis is thus accepted as true and hence substantiated. The results are in line with results of previous research studies (Škudienè, Augutytė, Demeško \& Suchockis, 2018; Eisenbeiss, Knippenberg \& Boerner, 2008; Siddique, Aslam, Khan \& Fatima, 2011; Naqvi, Ullah \& Javed, 2017; Afsar, Badir \& Saeed, 2014; Afsar \& Umrani, 2019). Consequently, the existing literature hence provides significant support to the results of the present study.

$\mathbf{H}_{4}$ : Transactional leadership has a positive and significant impact on innovative work behavior.

Table 6: Regression Analysis $\left(\mathrm{H}_{4}\right)$ (Model Summary)

\begin{tabular}{ccccc}
\hline Model & R & R Square & Adjusted R Square & Std. Error of Estimate \\
\hline 1 & $.457^{\text {a }}$ & .208 & .204 & .39727 \\
\hline a. Predictors: (Constant), Transactional Leadership & \\
\hline
\end{tabular}

Table 7: Regression Analysis $\left(\mathrm{H}_{4}\right)$ (ANOVA)

\begin{tabular}{llccccc}
\hline \multicolumn{2}{l}{ Model } & Sum of Squares & df & Mean Square & F & Sig. \\
\hline \multirow{2}{*}{1} & Regression & 8.231 & 1 & 8.231 & 52.154 & $.000^{\mathrm{b}}$ \\
\cline { 2 - 7 } & Residual & 31.250 & 198 & .158 & & \\
\cline { 2 - 7 } & Total & 39.481 & 199 & & & \\
\hline
\end{tabular}

a. Dependent Variable: Innovative Work Behavior

b. Predictors: (Constant), Transactional Leadership

Table 8: Regression Analysis $\left(\mathrm{H}_{4}\right)$ (Coefficients)

\begin{tabular}{|c|c|c|c|c|c|c|}
\hline \multirow{2}{*}{\multicolumn{2}{|c|}{ Model }} & \multicolumn{2}{|c|}{ Unstandardized Coefficients } & \multirow{2}{*}{$\begin{array}{c}\text { Standardized Coefficients } \\
\text { Beta }\end{array}$} & \multirow[t]{2}{*}{$\mathbf{t}$} & \multirow[t]{2}{*}{ Sig. } \\
\hline & & $\mathrm{B}$ & Std. Error & & & \\
\hline \multirow[t]{2}{*}{1} & (Constant) & 3.748 & .100 & & 37.584 & .000 \\
\hline & Transactional Leadership & -.252 & .035 & -.457 & -7.222 & .000 \\
\hline
\end{tabular}

a. Dependent Variable: Innovative Work Behavior

The regression results confirmed the significant but impact of transactional leadership on teachers' work innovative behavior as predicted over the fourth hypothesis through regression procedure. The results revealed further that transactional leadership has a significant impact on innovative work behavior over $20.8 \%$ change in $\mathrm{R}$ square and significant influence (-.252\& .000). From these results over regression, the fourth hypothesis is therefore rejected. These results are thus in line with results of existing studies (Khan, Aslam \& Riaz, 2012; Wu \& Lin, 2018; Carlo, Jean \& Boudrias, 2015; Kurt \& Yahyagil, 2015; Eisenbeiss, Knippenberg \& Boerner, 2008; Kwasi \& Emmanuel, 2015; Mukherjee \& Ray, 2009). Consequently, the existing literature hence provides significant support to the results of the present study. In this connection, the results of the present study provide significant information in deciding about the relationships among the research variables and reaching the conclusion of the study. 


\section{CONCLUSION}

This study was based on certain assumptions about the relationships between leadership styles and innovative work behavior in higher educational contexts. The existing research studies provide sufficient information about the relationship between these phenomena however, the present study further confirmed the relationships in a native environment. The results of the study revealed that transformational leadership has a significant association and influence on innovative work behavior, however, transactional leadership has a significant but negative impact on innovative work behavior. The results further revealed that the transformational process under transformational leadership is important in predicting innovative behavior. However, the negative relationship between transactional leadership and innovative work behavior revealed that the teacher never accepts the transactional and exchanged behavior from the transactional leaders in institutions as compared to other leadership styles. Transformational leadership is widely recognized as the best leadership style as validated and confirmed in the different contexts which have been also confirmed in the present study through statistical procedures thereby analyzing the data collected from the teachers hailing from higher educational institutions. Therefore, the results provide significant information in reaching a conclusion from which certain recommendations have been extracted 1for For management of higher institutions and for future researchers in getting practical guidelines from this study.

\section{RECOMMENDATIONS \& IMPLICATIONS}

$\checkmark$ The present study provides significant information about the relationships between leadership styles and innovative work behavior to validate the results of existing research studies on similar issues as already investigated in the different contexts with the different outcomes.

$\checkmark$ Transformational leadership has been examined over and again as the best leadership style towards employees' motivation and commitment along with ultimate performance. Thus, management of higher institutions is required to adopt transformational leadership in institutions.

$\checkmark$ The management of the higher institution is required to avoid the transactional behavior in the institution that is the concerned provision of the rewards and punishments which created anxieties and apprehensions among the employees in institutions and not accepted by employees.

$\checkmark$ The management of higher institutions is suggested to ensure the innovativeness and creativity in the institutions thereby allowing the employees to use the new techniques instead of traditional to attain the desired objectives with desired standards in concerned institutions.

$\checkmark$ The results of this study can be used as guidelines in nurturing the attitude and behavior of the employees in the institutions. The management of institutions can get guidelines for motivating the employees towards innovative behavior to achieve desired strategic objectives.

\section{LIMITATION \& FUTURE RESEARCH}

$\checkmark$ The present study is limited to only two leadership styles likewise the transformational and transactional leadership as well as innovative work behavior. The future researchers are required to examine some other leaderships styles to compare the results and extract new information.

$\checkmark$ The future researchers are suggested to examine these variables in other contexts to get the desired information and contribute to the existing database of knowledge. The results from other contexts may be compared with results in the present context to reach commonalities and differences.

$\checkmark$ The future researchers are suggested to use some other variables in connecting leadership styles and innovative work behavior like mediators (emotional intelligence, commitment \& motivation) to further strengthen the linkages between leadership styles and innovative behavior.

$\checkmark$ The future researchers are proposed to use some other variables in linking the leadership styles and work innovative behavior like the moderators (OCB, organizational politics \& employees' resilience) to further strengthen linkages amid leadership styles and innovative behavior.

$\checkmark$ The future researchers are required to use advanced tools and techniques from analyzing the data like the structural equation modeling to compare the results obtained from the traditional tools to reach the conclusion about the variation in results of present and future studies.

\section{CONTRIBUTION OF STUDY}

Muhammad Saqib Khan developed the main theme and ensure the systematic approach in the study.

Dr. Hamid Khan and Dr. Aman Ullah collected and analyzed the data along with interpretation. Muhammad Kamran and Dr. Muhammad Tariq performed the editing and revised of the article. 


\section{REFERENCES}

1. Afsar, B., \& Umrani, W. (2019). Transformational Leadership and Innovative Work Behavior. European Journal of Innovation Management, 23(3), 402-428. https://doi.org/10.1108/EJIM-12-2018-0257

2. Afsar, B., Badir, Y., \& Saeed, B., (2014). Transformational leadership and innovative work behavior. Industrial Management \& Data Systems, 114(8), 1270-1300. http:// //doi.org/10.1108/ IMDS-05-2014-0152

3. Alheeta, A., Ahmad, A., Ahmad, Y., \& Mohamed, S. (2021). The effect of leadership styles on employees' innovative work behavior. Management Science Letters, 11, 239-246. http:////doi.org/10.5267/j.msl.2020.8.010

4. Asad, A., Ismail, B., Hussain, A., \& Alghazali, B. (2020). The Interplay of Leadership Styles, Innovative Work Behavior, Organizational Culture, and Organizational Citizenship Behavior. SAGE Open, January-March (2020), 1-16. http://doi.org/10.1177/2158244019898264

5. Asare, A. E., Long, D., \& Murphy, W. D. (2005). Leadership best practices for sustaining quality in UK higher education from the perspective of the EFQM Excellence Model. Quality Assurance in Education, 13(2), 148170. https://eric.ed.gov/?id=EJ801748

6. Avolio, B. J., \& Bass, B. M. (2000). Individual consideration viewed at multiple levels of analysis: A multi-level framework for examining the diffusion of transformational leadership. The Leadership Quarterly, 6(2), 199-218. https://doi.org/10.1016/1048-9843(95)90035-7

7. Barrick, M.R., Mount, M.K. and Li, N. (2013). The theory of purposeful work behavior: the role of personality, higher-order goals, and job characteristics. Academy of Management Review, 38(1), 132-153. https://doi.org /10.5465/amr.2010.0479

8. Bolden, R., Georgy, P., \& Jonathan, G. (2009). Distributed Leadership in Higher Education Rhetoric and Reality. Educational Management Administration \& Leadership, 37(2), 257-277. https://doi.org/10.1177/ 1741143208100301

9. Carlo, O., Jean, F., \& Boudrias, A. (2015). Linking managerial practices and leadership style to innovative work behavior. Leadership \& Organization Development Journal, 36(5), 545 - 569. http:// doi.org/10.1108/LODJ-102013-0131

10. Cheng, C., Cao, L., Zhong, H., He, Y. \& Qian, J. (2019). The Influence of Leader Encouragement of Creativity on Innovation Speed: Findings from SEM and fsQCA. Sustainability, 11(9), 1-17. http:// doi.org/10.3390 /su11092693

11. Eisenbeiss, S., van Knippenberg, D. \& Boerner, S. (2008). Transformational leadership and team innovation: Integrating team climate principles. Journal of Applied Psychology, 93(6), 1438-1446. https://doi.org/1 $0.1037 / \mathrm{a} 0012716$

12. Erdogan, B., \& Enders, J. (2007). Support from the top: Supervisors' perceived organizational support as a moderator of leader-member exchange to satisfaction and performance relationships. Journal of applied psychology, 92(2), 321. http:// doi.org/10.1037/0021-9010.92.2.321

13. Gilson, L., \& Shalley, C. (2004). A little creativity goes a long way: an examination of teams' engagement in creative processes. Journal of Management, 30(4), 453-470. https://doi.org/10.1016/ j.jm.2003.07.001

14. Gómez L., Pujols A., Alvarado Y., Vargas L. (2018). Social Responsibility in Higher Educational Institutions: An Exploratory Study. In: Crowther D., Seifi S., Moyeen A. (eds) The Goals of Sustainable Development. Approaches to Global Sustainability, Markets, and Governance. Springer, Singapore. https://doi.org/10.1007/978-981-10-5047-3 13

15. Janssen, O., \& Yperen, N. W., (2004). Employees' goal orientations, the quality of leader- member exchange, and the outcomes of job performance and job satisfaction. Academy of management journal, 47(3), 368-384. https://doi.org/10.2307/20159587.

16. Kark, R., Van Dijk, D. \& Vashdi, D. (2018). Motivated or demotivated to be creative: The role of self-regulatory focus in transformational and transactional leadership processes. Applied Psychology, 67(1), 186-224. http://doi.org/10.1111/apps.12122.

17. Kezar, J., Rozana, K., \& Melissa, C. (2006). Rethinking the "leadership" Word in Higher Education: The Revolution of Research on Leadership. ASHE Higher Education Report, 31(6). San Francisco: Jossey-Bass.

18. Khan, M., Aslam, N. \& Riaz, M. (2012). Leadership styles as predictors of innovative work behavior. Pakistan Journal of Social \& Clinical Psychology, 9(2), 17-22. https://www.researchgate .net/publication/234092637

19. Kurt, İ. \& Yahyagil, M. Y. (2015). Universal values, creative behavior and leadership: Turkish case. International Business Research, 8(6), 89-103. http:// doi.org/10.5539/ibr.v8n6p89

20. Kwasi, D., \& Emmanuel, T. (2015). Examining the influence of transformational and transactional leadership styles on perceived job stress among Ghanaian banking employees. International Journal of Business and Management, 10(8), 161-170. https://doi.org/10.5539/ijbm.v10n8p

21. Li, X., \& Zheng, Y. (2014). The Influential Factors of Employees' Innovative Behavior and the Management Advices. Journal of Service Science and Management, 7(6), 446. https://doi.org/10.4236/jssm.2014.76042

22. Mukherjee, S. B., \& Ray, A. (2009). Innovative work behavior of managers: Implications regarding stressful challenges of modernized public and private sector organizations. Industrial Psychiatry Journal, 18(2), 101-107. http:// doi.org/10.4103/0972-6748.62269 
23. Naqvi, J., Ullah, S., \& Javed, B. (2017). Effect of Leadership Styles on Employees' Innovative Behavior: The Mediating Role of Employees' Creativity. European Journal of Business and Management, 9(28), 27-37. http://doi.org/10.5267/j.msl.2020.8.010

24. Sánchez, M., \& Mainardes, E. (2016). University social responsibility: A student base analysis in Brazil. International Review on Public and Nonprofit Marketing, 13(2), 151-169. http:// doi.org/10.1007/s12208-0160158-7

25. Sandra, J., M., Geraldine, L., \& Kevin, R. (2014). Synthesizing Theory and Practice: Distributed Leadership in Higher Education. Educational Management Administration \& Leadership 42(5), 603-619. http://doi.org/10.117 7/1741143213510506

26. Scott, S. G., \& Bruce, R. A. (1994). Determinants of innovative behavior: A path model of individual innovation in the workplace. Academy of management journal, 37(3), 580-607. https://doi.org /10.2307/256701

27. Sendjaya, S., Sarros, C., \& Santora, C. (2008). Defining and measuring servant leadership behaviour in organizations. Journal of Management studies, 45(2), 402-424. https://doi.org/10.1111/j.14676486.2 007.00761.x

28. Shalley, C. E., \& Gilson, L. L. (2004). What leaders need to know: A review of social and contextual factors that can foster or hinder creativity. The Leadership Quarterly, 15(1), 33-53. https://doi.org/10.1016/j.leaqua .2003.12.004

29. Siddique, A., Aslam, H. D., Khan, M., \& Fatima, U. (2011). Impact of academic leadership on faculty's motivation and organizational effectiveness in higher education system. International Journal of Academic Research, 3(3).

30. Škudienė, V., Augutytè, I., Demeško, N. \& Suchockis, A. (2018). Exploring the relationship between innovative work behavior and leadership: moderating effect of locus of control. Organizations and Markets in Emerging Economies, 9(1), 21-40. https://doi.org/10.15388/omee. 2018.10.00002

31. Vasilescu, R., Barna, C., Epure, M., \& Baicu, C. (2010). Developing university social responsibility: A model for the challenges of the new civil society. Procedia-Social and Behavioral Sciences, 2(2), 4177-4182. http://doi.org/10.1016/i.sbspro.2010.03.660

32. Voon, M., Lo, C., Ngui, K., \& Ayob, B. (2011). The influence of leadership styles on employees' job satisfaction in public sector organizations in Malaysia. International Journal of Business, Management and Social Sciences, 2(1), 24-32.

33. Wu, J. \& Lin, Y. (2018). Interaction between the different leadership styles on innovative behavior based on organizational culture in ecological industry: Empirical research from China, EKOLOJI, 27(106), 643-649.

34. Yamani, T. (1967). The Statistics: An Introductory Analysis, 2nd Edition, The New York: Harper and Row.

35. Zhang, X., \& Bartol, K. M. (2010). Linking empowering leadership and employee creativity: The influence of psychological empowerment, intrinsic motivation, and creative process engagement. Academy of management journal, 53(1), 107-128. https://www.jstor.org/stable/25684309 